\title{
The modifications to the requirements on energy savings and thermal insulation of buildings in Poland in the years 1974-2021
}

\author{
Anna Życzyńska ${ }^{1}$, Tomasz Cholewa² \\ ${ }^{I}$ Department of Historic Building Preservation, Faculty of Civil Engineering and Architecture, \\ Lublin University of Technology, e-mail: a.zyczynska@pollub.pl \\ ${ }^{2}$ Faculty of Environmental Engineering, Lublin University of Technology, \\ e-mail:t.cholewa@wis.pol.lublin.pl
}

\begin{abstract}
Residential and public buildings use for heating more than $40 \%$ of the total energy consumption in the European Union. Therefore, this paper discusses the modifications to the building energy standard, which is currently in force. It is based on the requirements included in the Polish technical building regulations and standards. The proper energy-saving police have been implemented to this kind of consumers to diminish the energy consumption.

The analysis pertains to the values of heat transfer coefficients of building partitions as well as the indexes of the energy demand for various types of buildings. The analysis was conducted between 1974 and 2013. Moreover; the changes within this range, which will come into force in 2014 and will continue to 2021, which act in accordance with the technical requirements suitable for buildings, were also discussed. Furthermore, minimal thicknesses of insulation materials which enable meeting this requirements of a heat transfer coefficient for building partitions, were examined in the article.

Keywords: heat transfer coefficient, energy policy, insulation thickness, usable energy, non-renewable primary energy demand index, building energy standard, energy saving.
\end{abstract}

\section{Introduction}

Energy-saving policy applied for buildings has significant global impact. Energy consumption in buildings in developed countries comprises $20 \%-40 \%$ of the world final energy consumption [1]. What is more, about $63 \%$ of the total energy consumption in the European buildings sector is also used in residential buildings [2].

Indeed, there are a lot of technical and social possibilities to reduce energy consumption in existing buildings; for instance, described by Ueno et al. [3] and by Ouyang and Hokao [4], who proposed improving the occupants' domestic energy consumption through education about energy saving behaviour.

But to reduce the energy consumption in future buildings, designers should choose the proper heating system and the source of its energy supply [5-7]; what is not naturally the fundamental and the cheapest version, and is not very often used in the final version of the project after consultations with investors.

From another side, energy savings polices, which are obligatory, may significantly contribute to energy savings, what was also described in [8-12].

This situation may be seen in Poland (see Fig. 1), where the energy consumption per one person declines to a greater extent in comparison to EU27. 


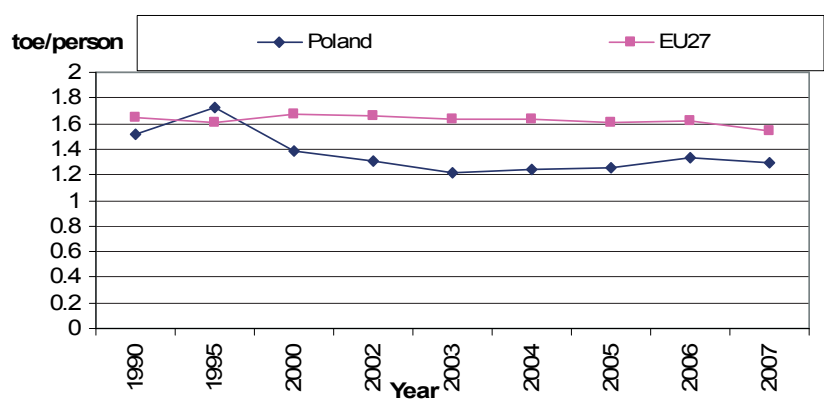

Fig. 1. Energy consumption in households per one person in Poland and EU27 [13]

Therefore, the objective of this study was to show energy-saving policy used in Poland since 1974. What is more, it is also a prospective policy for 2021 treated as exemplary influence of energy policy on the energy conservation, which is on the top of commonly accepted energy hierarchy.

\section{Energy-saving policies in Poland}

During the design of a new building or the modernisation of an existing one, it is necessary to take the building energy standard requirements into account since they are frequently defined as requirements for a building in terms of its energy consumption. For over 30 years, the energy saving alterations have been introduced to the binding standards [14-16] or technical building regulations [17,18]. Firstly, the changes referred only to maximal values of heat transfer coefficients (marked with ' $\mathrm{k}$ ' then ' $\mathrm{K}$ ' and finally ' $\mathrm{U}$ ' expressed in $\left[\mathrm{Wm}^{-2} \mathrm{~K}^{-1}\right]$ for the opaque and transparent partitions. In 1998, the regulation which aimed at supporting thermomodernisation investments $[19,20]$ was passed together with the executory order [21], which showed that thermomodernised buildings should have better thermal insulation parameters than the newly built ones. Furthermore, in 2002, additional requirements were introduced on the maximal (boundary) value of the index of seasonal heat demand for heating. Such an index (marked with $E$ and expressed in [kWh m ${ }^{3}$ year $\left.^{-1}\right]$ ) showed only building demand for usable energy; and thus, it should be calculated in accordance with Polish Standard [21]. The boundary value (marked with $E_{0}$ ) depended on the building shape coefficient (marked with $A / V$, where $A$ in $\left[\mathrm{m}^{2}\right]$ was the total sum of the area of all partitions separating the heated space from the outdoor air, the unheated space and ground, calculated by the external outline, $V$ in $\left[\mathrm{m}^{3}\right]$ - net cubic volume of a heated part of building). In 2008, the requirement concerning the building demand for nonrenewable primary energy was introduced to the domestic regulations. It determined the maximal value of annual index calculation of the demand for heating, ventilation, cooling, warm water preparation for residential buildings. When it comes to other buildings, there is also a demand for the built-in lighting. This index is marked with $E P$, and its value is expressed in $\left[\mathrm{kWh} \mathrm{m}^{-2}\right.$ year $\left.^{-1}\right]$. Formulas allowing for the calculation of its boundary values for, a socalled, reference building depending on its function, shape coefficient and cooling facilities, are stated in the technical building regulations [17]. The requirements for the thermal insulation of building partitions were implemented simultaneously with the introduction of $E$ and $E P$; and additionally, in 2008 together with the thermal insulation of conduits, fittings and fixtures in installations. In 2002, the provisions which referred to the energy efficiency of fixtures and keeping the energy demand in a building at a reasonably low level, were introduced for the first time in the Decree of the Minister of Infrastructure [17]. 
The affiliation of Poland to the EU caused the necessity to implement the Directive 2002/91/EC known as "The energetic characteristics of buildings." In Poland, it was realised by the introduction of modifications to the Building Code Act as well as the executive regulation [23] and changes to the regulations [17,21]. The obligation to perform the energy characteristics of a building at the stage of its design, opening, sale or lease was imposed the $1^{\text {st }}$ of January, 2009. The uniformed methodology to determine the integrated building energy characteristics as well as draft the energy certificates in accordance with uniformed formulas presented in the Decree of the Minister of Infrastructure [23] came also into force. Furthermore, the obligation to conduct periodic inspections of boilers and air conditioning installations; not only in terms of their technical state, but first and foremost, due to the efficiency to generate energy and the correctness of choice of power capacity adapted to the building demand. In the modified technical building regulations [18]; effective from January 2014; the schedule for the years 2014-2021 was established. When it comes to its requirements on the thermal insulation of partitions and $E P$ index, they are even more strict.

\subsection{Heat transfer coefficient $(U)$}

\subsubsection{Opaque partitions}

The maximal values of heat transfer coefficients (U) for various types of opaque partitions, effective in accordance with technical building regulations at particular periods, values binding during the preparation of energy audits used for obtaining thermomodernisation funds and the requirements (valid since January 2014, in accordance with Decree of the Minister of Infrastructure, Construction and Maritime Economy [18], are presented in Table 1. It demonstrates progressive changes and the extent to which the requirements are tightened within this scope, for the inside temperature of a heated room or with the difference between the heated and unheated space of at least $16^{\circ} \mathrm{C}$.

Table 1. The values of heat transfer coefficient for the selected building partitions

\begin{tabular}{|c|c|c|c|c|c|c|c|c|c|}
\hline \multirow{3}{*}{ Partition type } & \multicolumn{9}{|c|}{$\begin{array}{l}\text { Heat transfer coefficient } U\left[\mathrm{~W} \mathrm{~m}^{-2} \mathrm{~K}^{-1}\right] \\
\text { * public utility and manufacturing buildings } \\
* * \text { manufacturing, warehouse, outhouse buildings }\end{array}$} \\
\hline & \multirow[b]{2}{*}{1974} & \multirow[b]{2}{*}{1982} & \multirow[b]{2}{*}{1991} & \multirow[b]{2}{*}{2002} & \multirow[b]{2}{*}{2008} & \multirow[b]{2}{*}{1998} & \multicolumn{3}{|c|}{ acc. to Decree of the Minister [18] } \\
\hline & & & & & & & $\begin{array}{c}\text { since } \\
01.01 .2014\end{array}$ & $\begin{array}{l}\text { since } \\
1.01 .2017\end{array}$ & $\begin{array}{c}\text { since } \\
701.01 .2021\end{array}$ \\
\hline $\begin{array}{l}\text { External wall when } t_{i} \geq \\
16^{0}\end{array}$ & 1.16 & 0.75 & 0.55 & $\begin{array}{l}0.30 \\
0.45^{*}\end{array}$ & 0.30 & 0.25 & 0.25 & 0.23 & 0.20 \\
\hline $\begin{array}{l}\text { Internal walls } \\
\text { separating heated from } \\
\text { unheated rooms }\end{array}$ & 1.45 & 1.00 & 1.00 & 1.00 & 1.00 & 0.25 & 0.30 & 0.30 & 0.30 \\
\hline $\begin{array}{l}\text { roofs, flat roofs, } \\
\text { ceilings above crossings }\end{array}$ & 0.70 & 0.45 & $\begin{array}{c}0.30 \\
0.45^{* *} \\
\end{array}$ & 0.30 & 0.25 & 0.22 & 0.20 & 0.18 & 0.15 \\
\hline $\begin{array}{l}\text { Ceilings below the } \\
\text { unheated attic }\end{array}$ & 0.93 & 0.40 & 0.30 & 0.30 & 0.25 & 0.22 & 0.20 & 0.18 & 0.15 \\
\hline $\begin{array}{l}\text { Ceilings above heated } \\
\text { and unheated rooms }\end{array}$ & 1.16 & 1.00 & $\begin{array}{l}0.60 \\
1.00^{* *} \\
\end{array}$ & 0.60 & $\begin{array}{c}0.45 \\
0.80^{* *} \\
\end{array}$ & 0.50 & 0.25 & 0.25 & 0.25 \\
\hline Floors on ground & 1.16 & 0.60 & 0.67 & 0.67 & 0.50 & $-^{(1)}$ & 0.30 & 0.30 & 0.30 \\
\hline $\begin{array}{l}\text { Walls adjoining to } \\
\text { ground }\end{array}$ & $-^{(2)}$ & 1.00 & 1.00 & 1.00 & $-^{(1)}$ & $-^{(1)}$ & $-^{(1)}$ & $-^{(1)}$ & $-^{(1)}$ \\
\hline
\end{tabular}

(1) - not determined, (2)- without requirements 


\subsubsection{Windows, balcony doors and exterior doors}

Similarly to the item 2.1.2, the maximal values of heat transfer coefficients $(U)$ of windows and balcony doors are displayed in Table 2; whereas, in the case of exterior doors they are presented in Table 3 . The tables illustrate continuous changes and the extent to which the requirements for various types of buildings, allowing for different internal temperatures and a climate zone, are tightened.

Table 2. The values of heat transfer coefficient for windows and balcony doors

\begin{tabular}{|c|c|c|c|c|c|c|c|c|c|}
\hline \multirow{3}{*}{ Partition type } & \multicolumn{9}{|c|}{ Heat transfer coefficient $U\left[\mathrm{~W} \mathrm{~m} \mathrm{~m}^{-2} \mathrm{~K}^{-1}\right]$} \\
\hline & \multirow[b]{2}{*}{1974} & \multirow[b]{2}{*}{1982} & \multirow[b]{2}{*}{1991} & \multirow[b]{2}{*}{2002} & \multirow[b]{2}{*}{2008} & \multirow[b]{2}{*}{$\begin{array}{c}1998 \\
\mathrm{~A}\end{array}$} & \multicolumn{3}{|c|}{$\begin{array}{l}\text { acc. to Decree of the Minister } \\
{[18]}\end{array}$} \\
\hline & & & & & & & $\begin{array}{c}\text { sine } \\
01.01 \\
2014 \\
\end{array}$ & $\begin{array}{c}\text { sine } \\
01.01 \\
2017\end{array}$ & $\begin{array}{c}\text { since } \\
01.01 \\
2021 \\
\end{array}$ \\
\hline $\begin{array}{l}\text { Windows in residential and } \\
\text { multi-apartment residential } \\
\text { buildings I, II, III zone, } \\
t_{i} \geq 16^{0} \mathrm{C}\end{array}$ & $\begin{array}{c}2.0 \div \\
5.8\end{array}$ & 2.6 & 2.6 & 2.6 & 1.8 & 1.9 & 1.3 & 1.1 & 0.9 \\
\hline $\begin{array}{l}\text { Windows in residential and } \\
\text { multi-apartment residential } \\
\text { buildings IV and V zone, } \\
t_{i} \geq 16^{\circ} \mathrm{C}\end{array}$ & $\begin{array}{c}2.0 \div \\
5.8\end{array}$ & 2.0 & 2.0 & 2.0 & 1.7 & 1.7 & 1.3 & 1.1 & 0.9 \\
\hline Roof windows $t_{i} \geq 16^{\circ} \mathrm{C}$ & $\begin{array}{c}2.0 \div \\
5.8\end{array}$ & $-(1)$ & $-{ }^{(1)}$ & 2.0 & 1.8 & $\begin{array}{l}1.8 \\
1.7\end{array}$ & 1.5 & 1.3 & 1.1 \\
\hline Roof windows $t_{i}<16^{\circ} \mathrm{C}$ & $\begin{array}{c}2.0 \div \\
5.8\end{array}$ & $-(1)$ & $-{ }^{(1)}$ & $-^{(1)}$ & 1.8 & $-^{(1)}$ & 1.8 & 1.6 & 1.4 \\
\hline $\begin{array}{l}\text { Windows in public utility } \\
\text { buildings } t_{i} \geq 16^{0} \mathrm{C}\end{array}$ & $\begin{array}{c}2.0 \div \\
5.8\end{array}$ & $\begin{array}{c}2.6 \\
\text { or } \\
2.0\end{array}$ & $\begin{array}{c}2.6 \\
\text { or } \\
2.0\end{array}$ & 2.3 & 1.8 & $-^{(2)}$ & 1.3 & 1.1 & 0.9 \\
\hline $\begin{array}{l}\text { Windows in public utility } \\
\text { buildings } 8^{0} \mathrm{C}<t_{i}<16^{\circ} \mathrm{C}\end{array}$ & $\begin{array}{c}2.0 \div \\
5.8\end{array}$ & 4.0 & 4.0 & 2.6 & 2.6 & $\_^{(2)}$ & 1.8 & 1.6 & 1.4 \\
\hline $\begin{array}{l}\text { Windows in manufacturing } \\
\text { buildings } \mathrm{t}_{\mathrm{i}} \geq 20^{\circ} \mathrm{C}\end{array}$ & $\begin{array}{c}2.0 \div \\
5.8\end{array}$ & 2.6 & 2.6 & 2.6 & $\begin{array}{c}1.9 \\
\text { or } \\
1.7\end{array}$ & $-^{(2)}$ & 1.3 & 1.1 & 0.9 \\
\hline $\begin{array}{l}\text { Windows in manufacturing } \\
\text { buildings } 12^{0} \mathrm{C}<t_{i}<20^{\circ} \mathrm{C}\end{array}$ & $\begin{array}{c}2.0 \div \\
5.8\end{array}$ & 4.0 & 4.0 & 4.0 & $\begin{array}{c}1.9 \\
\text { or } \\
1.7\end{array}$ & $-^{(2)}$ & 1.8 & 1.6 & 1.4 \\
\hline
\end{tabular}

(1) - Not determined, (2) - As for residential

Table 3. The values of heat transfer coefficient for exterior doors

\begin{tabular}{|c|c|c|c|c|c|c|c|c|c|}
\hline \multirow{3}{*}{ Partition type } & \multicolumn{9}{|c|}{ Heat transfer coefficient $U\left[\mathrm{~W} \mathrm{~m}{ }^{-2} \mathrm{~K}^{-1}\right]$} \\
\hline & \multirow[b]{2}{*}{1974} & \multirow[b]{2}{*}{1982} & \multirow[b]{2}{*}{1991} & \multirow[b]{2}{*}{2002} & \multirow[b]{2}{*}{2008} & \multirow{2}{*}{$\begin{array}{c}1998 \\
\text { A }\end{array}$} & \multicolumn{3}{|c|}{ acc. to Decree of the Minister [18] } \\
\hline & & & & & & & $\begin{array}{c}\text { since } \\
01.01 .2014\end{array}$ & $\begin{array}{c}\text { since } \\
01.01 .2017\end{array}$ & $\begin{array}{c}\text { since } \\
01.01 .2021\end{array}$ \\
\hline $\begin{array}{l}\text { Doors in residential and } \\
\text { multi-apartment } \\
\text { residential buildings }\end{array}$ & $\begin{array}{c}1.6 \div \\
5.8\end{array}$ & $\begin{array}{l}1.1 \div \\
5.6\end{array}$ & 3.0 & 2.6 & 2.6 & $-^{(1)}$ & 1.7 & 1.5 & 1.3 \\
\hline $\begin{array}{l}\text { Doors in public utility } \\
\text { buildings }\end{array}$ & $\begin{array}{c}1.6 \div \\
5.8\end{array}$ & $\begin{array}{c}1.1 \div \\
5.6\end{array}$ & 3.0 & 2.6 & 2.6 & $-^{(1)}$ & 1.7 & 1.5 & 1.3 \\
\hline $\begin{array}{l}\text { Doors in manufacturing } \\
\text { buildings }\end{array}$ & $\begin{array}{c}1.6 \div- \\
5.8\end{array}$ & $\begin{array}{c}1.1 \div \\
5.6\end{array}$ & $\begin{array}{l}1.4 ; \\
3.0\end{array}$ & $\begin{array}{l}1.4 ; \\
3.0\end{array}$ & 2.6 & $-^{(1)}$ & 1.7 & 1.5 & 1.3 \\
\hline
\end{tabular}

(1) - Not determined 


\subsection{The index of usable energy demand $(E)$}

In April 2002 [17], the requirement referring to the index boundary values $E_{0}$ (seasonal demand for thermal energy to heat a building) was introduced for the first time to the regulation "concerning technical requirements, which buildings and their locations should comply with" for multi-family and multi-apartment buildings as well as for a single family building. The index boundary values $E_{0}$ is calculated according to the dependencies presented in Table $4\left(E_{0}{ }^{*}\right.$ is given for 2.5 meters of room clear height) and by taking the shape coefficient of building $(A / V)$ into account. When it comes to the calculations of $E$ index, the Polish Standard [22] was valid. The requirements of regulation on energy savings and thermal insulation were assumed to be fulfilled for a single family building if the building partitions complied with the requirements of heat transfer coefficients $(U)$ or $E$ value did not exceed $E_{0}$ value; whereas as for multi-family and multi-apartment buildings, the requirements of $E$ and $U$ should be met. In the case of a public utility building and manufacturing building, it was sufficient to meet the requirements of U. Such provisions were in force until November 2008.

Table 4 . The boundary values $E_{0}$ according to the Decree of the Minister of Infrastructure [17]

\begin{tabular}{cccc}
\hline \multirow{2}{*}{$\begin{array}{c}\text { Number of } \\
\text { case }\end{array}$} & $A / V$ & $E_{0}$ & $E_{0}{ }^{*}$ \\
\cline { 2 - 4 } & {$\left[\mathrm{m}^{-1}\right]$} & {$\left[\mathrm{kWh} \mathrm{m}^{-3} \mathrm{year}^{-1}\right]$} & {$\left[\mathrm{kWh} \mathrm{m}^{-3}\right.$ year $\left.^{-1}\right]$} \\
\hline 1 & $\leq 0.20$ & 29.0 & 72.5 \\
\hline 2 & $0.20 \div 0.90$ & $26.6+12 \cdot A / V$ & $2.5 \cdot(26.6+12 \cdot A / V)$ \\
\hline 3 & $\geq 0.90$ & 37.4 & 93.5 \\
\hline
\end{tabular}

\subsection{The index of the demand for nonrenewable primary energy $(E P)$}

In November 2008, together with the regulations compulsory to perform the energy characteristics of a building, the provisions on determining the boundary index values of the demand for nonrenewable primary energy EP expressed in $\left[\mathrm{kWh} \mathrm{m}^{-2} \mathrm{year}^{-1}\right]$, entered into force. The buildings were divided according to the two criteria i.e. the function and the occurrence of a cooling installation. While determining EP index, the energy for different purposes should be taken into consideration depending on the building adherence to a given group, which is presented in Table 5.

Table 5. Criteria for the division and types of energy demands of a building

\begin{tabular}{lcccc}
\hline \multicolumn{1}{c}{ Building type } & $\begin{array}{c}\text { Energy for } \\
\text { heating and } \\
\text { ventilation }\end{array}$ & $\begin{array}{c}\text { Energy for } \\
\text { the hot water } \\
\text { preparation }\end{array}$ & $\begin{array}{c}\text { Energy for } \\
\text { cooling }\end{array}$ & $\begin{array}{c}\text { Energy for } \\
\text { built-in } \\
\text { lighting }\end{array}$ \\
\hline $\begin{array}{l}\text { Residential building without a cooling } \\
\text { installation }\end{array}$ & + & + & - & - \\
\hline $\begin{array}{l}\text { Residential building with a cooling } \\
\text { installation }\end{array}$ & + & + & + & - \\
\hline $\begin{array}{l}\text { Multi-apartment, public utility or } \\
\text { manufacturing building without a cooling } \\
\text { installation }\end{array}$ & + & + & + \\
\hline $\begin{array}{l}\text { Multi-apartment, public utility or } \\
\text { manufacturing building with a cooling } \\
\text { installation }\end{array}$ & + & + & + \\
\hline $\begin{array}{l}\text { + the demand for energy should be determined } \\
\text { - the demand for energy should not be determined }\end{array}$ & & + \\
\hline
\end{tabular}


Table 6. The determination of index value EP according to the Decree of the Minister of Infrastructure, 2008

\begin{tabular}{|c|c|c|}
\hline \multirow{3}{*}{ Type of energy demand } & \multicolumn{2}{|c|}{ Determination method $E P\left[\mathrm{kWh} \mathrm{m}^{-2}\right.$ year $\left.^{-1}\right]$} \\
\hline & \multicolumn{2}{|c|}{ Building type } \\
\hline & Residential building & $\begin{array}{l}\text { Multi-apartment, public utility, manufactur- } \\
\text { ing building }\end{array}$ \\
\hline \multirow{3}{*}{$\begin{array}{l}\text { For heating and } \\
\text { ventilation }\end{array}$} & $A / V_{e} \leq 0.2 E P_{H}=73$ & \\
\hline & $0.2 \leq A / V_{e} \leq 1.05 E P_{H}=55+90$. & $\left(A / V_{e}\right)$ \\
\hline & $A / V_{e} \geq 1.05 E P_{H}=149.5$ & \\
\hline $\begin{array}{l}\text { For the hot water } \\
\text { preparation }\end{array}$ & $\Delta E P_{W}=7800 /\left(300+0.1 \cdot A_{f}\right)$ & $\Delta E P_{W}=1.56 \cdot 19.10 \cdot V_{c w} \cdot b_{t} / a_{l}$ \\
\hline For cooling & $\begin{array}{l}\Delta E P_{C}=\left(5+15 \cdot A_{w, e} / A_{f}\right)(1- \\
\left.0.2 \cdot A / V_{e}\right) \cdot A_{f, c} / A_{f}\end{array}$ & $\Delta E P_{C}=\left(10+60 \cdot A_{w, e} / A_{t}\right)\left(1-0.2 \cdot A / V_{e}\right) \cdot A_{f, c} / A_{f}$ \\
\hline For built-in lighting & Not determined & $\Delta E P_{L}=2.7 \cdot P_{N} \cdot t_{0} / 1000$ \\
\hline EP value & $\begin{array}{l}E P_{H+W}=E P_{H}+\Delta E P_{W} \text { or } \\
E P_{H+W+C}=E P_{H}+\Delta E P_{W}+\Delta E P_{C}\end{array}$ & $\begin{array}{l}E P_{H+W+L}=E P_{H}+\Delta E P_{W}+\Delta E P_{L} \\
E P_{H+W+C+L}=E P_{H}+\Delta E P_{W}+\Delta E P_{L}+\Delta E P_{C}\end{array}$ \\
\hline \multicolumn{3}{|c|}{$\begin{array}{l}\text { where: } \\
A_{f}-\text { heated usable area, } A \text { - total area of partitions separating heated part from outside air, ground, and the } \\
\text { unheated part, } V_{e}-\text { heated cubic volume, } A / V_{e}-\text { shape coefficient of a building, } A_{w, e}-\text { area of external walls } \\
\text { calculated by the external outline of a building, } A_{f, c}-\text { cooled usable area, } V_{c w}-\text { unitary daily consumption of } \\
\text { water per one reference unit }\left[\mathrm{dm}^{3} \text { day }{ }^{-1}\right], b_{t}-\text { dimensionless time of the use of warm water system per } \\
\text { annum, } a_{l}-\text { share of area } A_{f} \text { per one reference unit, } P_{N} \text { - electric power reference [ }\left[\mathrm{Wm}^{-2}\right], t_{0}-\text { time of } \\
\text { lighting use per annum }\left[\mathrm{h} \mathrm{year}^{-1}\right]\end{array}$} \\
\hline
\end{tabular}

Table 7. Requirements on EP according to the Decree of the Minister of Infrastructure, Construction and Maritime Economy (2013) in force since 01.01.2014

\begin{tabular}{|c|c|c|c|c|}
\hline Type of energy demand & Building type & \multicolumn{3}{|c|}{$\begin{array}{l}\text { Maximal index value of nonrenewable primary energy } \\
\text { demand }\left[\mathrm{kWh} \mathrm{m}^{-2} \text { year }^{-1}\right]\end{array}$} \\
\hline - & - & $\begin{array}{l}\text { since } 1 \text { January } \\
2014 \\
\end{array}$ & $\begin{array}{c}\text { since 1 January } \\
2017 \\
\end{array}$ & $\begin{array}{c}\text { since } 1 \text { January } \\
2021 \\
\end{array}$ \\
\hline \multirow{4}{*}{$\begin{array}{l}\text { for heating and warm } \\
\text { water preparation } \\
E P_{H+W}\end{array}$} & $\begin{array}{l}\text { residential: } \\
\text { - single family } \\
\text { - multi-family }\end{array}$ & $\begin{array}{l}120 \\
105\end{array}$ & $\begin{array}{l}95 \\
85\end{array}$ & $\begin{array}{l}70 \\
65\end{array}$ \\
\hline & multi-apartment & 95 & 85 & 75 \\
\hline & $\begin{array}{l}\text { public utility: } \\
\text { - public health care } \\
\text { - other }\end{array}$ & $\begin{array}{l}390 \\
65\end{array}$ & $\begin{array}{c}290 \\
60\end{array}$ & $\begin{array}{c}190 \\
45\end{array}$ \\
\hline & $\begin{array}{l}\text { farm building } \\
\text { warehouse } \\
\text { manufacturing }\end{array}$ & 110 & 90 & 70 \\
\hline \multirow{3}{*}{$\begin{array}{l}\text { for cooling } \\
\Delta E P_{C}\end{array}$} & residential & $\Delta E P_{C}=10 \cdot A_{f, c} / A_{f}$ & & $\Delta E P_{C}=5 \cdot A_{f, c} / A_{f}$ \\
\hline & other & $\Delta E P_{C}=25 \cdot A_{f, c} / A_{f}$ & & \\
\hline & residential & not applicable & & \\
\hline \multirow{4}{*}{$\begin{array}{l}\text { for built-in lighting } \\
\triangle E P_{L}\end{array}$} & \multirow{4}{*}{ other } & $\Delta E P_{L}=50$ & & $\Delta E P_{L}=25$ \\
\hline & & operating time up & $2500 \mathrm{~h} /$ year & \\
\hline & & $\Delta E P_{L}=100$ & & $\Delta E P_{L}=50$ \\
\hline & & operating time abo & e $2500 \mathrm{~h} /$ year & \\
\hline \multirow{4}{*}{$E P$ value } & \multicolumn{4}{|c|}{ residential buildings without cooling: $E P=E P_{H+W}$} \\
\hline & \multicolumn{4}{|c|}{ residential buildings with cooling: $E P=E P_{H+W}+\Delta E P_{C}$} \\
\hline & \multicolumn{4}{|c|}{ other buildings without cooling: $E P=E P_{H+W}+\Delta E P_{L}$} \\
\hline & \multicolumn{4}{|c|}{ other buildings with cooling: $E P=E P_{H+W}+\Delta E P_{C}+\Delta E P_{L}$} \\
\hline
\end{tabular}


Whereas, the provisions enabling the determination of the boundary values of $E P$ index are shown in Table 6. It should also be stated that as for a reconstructed building, it is permitted to increase these values no more than $15 \%$. These regulations were in force until the $31^{\text {st }}$ of December, 2013. Nevertheless, as in the case of tightening the requirements of heat transfer coefficients $\mathrm{U}$, stringent requirements concerning the boundary values of $E P$ index and the modifications to the manner of its calculation were introduced since the $1^{\text {st }}$ of January, 2014. The modifications and their time schedule are demonstrated in Table 7.

\section{A case study}

This case study compares the boundary values $E P$ according to still valid technical building regulations to the values which have come in force in January 2014. Three types of buildings were selected to the analysis: a multi-family building, a nursing home and an office building. The characteristic parameters of the buildings are shape coefficient of a building $\left(A / V_{e}\right)$ equal to 0.6 , heated usable area $\left(A_{f}\right)$ equal to $1000 \mathrm{~m}^{2}$ and area of external walls calculated by the external outline of a building $\left(A_{w, e}\right)$ equal to $1300 \mathrm{~m}^{2}$. It was also assumed that the whole area $\left(A_{f}\right)$ is cooled (when a cooling installation occurs in a building). All calculations on this section are performed in accordance with the Decree of the Minister of Infrastructure, Construction and Maritime Economy [18], EN ISO 13790 [24] and EN ISO 6946 [25].

The results of this analysis are shown in Table 8 and in Figure 2.

Table 8. Sample boundary values of EP index

\begin{tabular}{|c|c|c|c|c|c|c|c|c|c|}
\hline \multirow{3}{*}{ EP } & \multirow{3}{*}{\multicolumn{2}{|c|}{ Legal basis }} & \multirow{3}{*}{$\begin{array}{c}\text { Type of energy } \\
\text { demand }\end{array}$} & \multicolumn{6}{|c|}{ Type of the building } \\
\hline & & & & \multicolumn{2}{|c|}{$\begin{array}{c}\text { multi-family } \\
\text { building }\end{array}$} & \multicolumn{2}{|c|}{ nursing home } & \multicolumn{2}{|c|}{ office } \\
\hline & & & & $\begin{array}{l}\text { without } \\
\text { cooling }\end{array}$ & $\begin{array}{c}\text { with } \\
\text { cooling }\end{array}$ & $\begin{array}{l}\text { without } \\
\text { cooling }\end{array}$ & $\begin{array}{l}\text { with } \\
\text { cooling }\end{array}$ & $\begin{array}{l}\text { without } \\
\text { cooling }\end{array}$ & $\begin{array}{c}\text { with } \\
\text { cooling }\end{array}$ \\
\hline \multirow{17}{*}{ 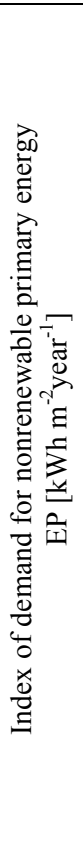 } & \multirow{5}{*}{ 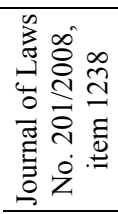 } & \multirow{5}{*}{ 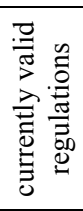 } & heating & 109 & 109 & 109 & 109 & 109 & 109 \\
\hline & & & warm water & 19.5 & 19.5 & 435.8 & 435.8 & 6 & 6 \\
\hline & & & cooling & - & 21.6 & - & 77.4 & - & 77.4 \\
\hline & & & lighting & - & - & 337.5 & 337.5 & 135 & 135 \\
\hline & & & IN TOTAL & 128.5 & 150.1 & 882.3 & 959.7 & 250.0 & 327.4 \\
\hline & \multirow{12}{*}{ 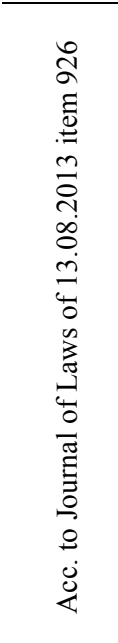 } & \multirow{4}{*}{ 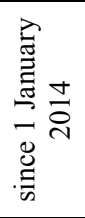 } & $\begin{array}{l}\text { heating and } \\
\text { warm water }\end{array}$ & 105 & 105 & 390 & 390 & 65 & 65 \\
\hline & & & cooling & - & 10 & - & 25 & - & 25 \\
\hline & & & lighting & - & - & 100 & 100 & 50 & 50 \\
\hline & & & IN TOTAL & 105 & 115 & 490 & 515 & 115 & 140 \\
\hline & & \multirow{4}{*}{ 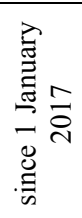 } & $\begin{array}{l}\text { heating and } \\
\text { warm water }\end{array}$ & 85 & 85 & 290 & 290 & 60 & 60 \\
\hline & & & cooling & - & 10 & - & 25 & - & 25 \\
\hline & & & lighting & - & - & 100 & 100 & 50 & 50 \\
\hline & & & IN TOTAL & 85 & 95 & 390 & 415 & 110 & 135 \\
\hline & & \multirow{4}{*}{ 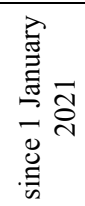 } & $\begin{array}{l}\text { heating and } \\
\text { warm water }\end{array}$ & 65 & 65 & 190 & 190 & 45 & 45 \\
\hline & & & cooling & - & 5 & - & 25 & - & 25 \\
\hline & & & lighting & - & - & 50 & 50 & 25 & 25 \\
\hline & & & IN TOTAL & 65 & 70 & 240 & 265 & 70 & 95 \\
\hline
\end{tabular}




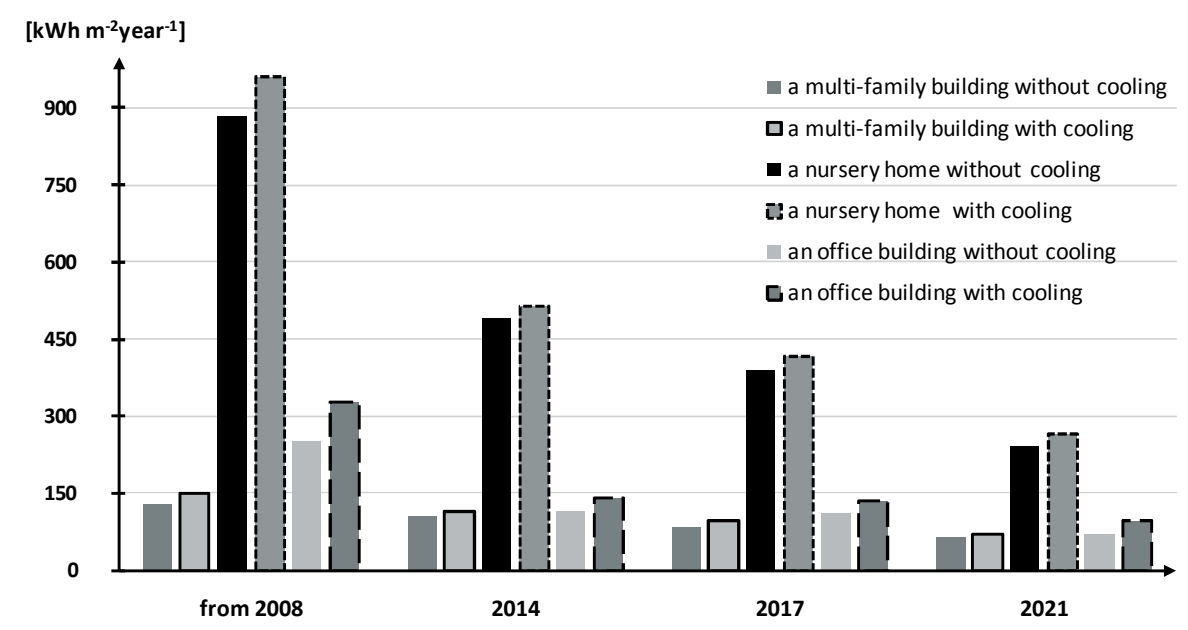

Fig. 2. EP boundary value for particular types of buildings

By contrast, the modification of thermal insulation of building partitions is based on continuous decrease in the maximal values of heat transfer coefficients $(U)$ of these partitions. As a result, in new building or while reconstructing existing ones, there is a necessity to apply bigger thickness of traditional insulation materials or to replace them with materials with lower heat conductivity coefficient $(\lambda)$. The minimal thicknesses of insulation materials for various $\lambda$ values, for sample $U$ values in initial condition and target $U$ values consistent with valid technical building regulations, are presented in Table 9 for the external wall, and in Table 10 for the flat roof. Moreover, the difference in the trade thickness of insulation $(\Delta d)$ between current requirements and target ones in 2021, was calculated.

Table 9. The minimal insulation thickness for an external wall

\begin{tabular}{cccccccc}
\hline \multirow{2}{*}{$\begin{array}{c}\text { Initial value } U \\
{\left[\mathrm{~W} \mathrm{~m}^{-2} \mathrm{~K}^{-1}\right]}\end{array}$} & $\begin{array}{c}\lambda \text { of insulation } \\
\text { material } \\
{\left[\mathrm{W} \mathrm{m}^{-1} \mathrm{~K}^{-1}\right]}\end{array}$ & \multicolumn{5}{c}{$d$-insulation thickness [cm] } \\
\cline { 2 - 7 } & 0.30 & 0.28 & 0.25 & 0.23 & 0.20 & $\Delta d$ trade [cm] \\
\hline \multirow{2}{*}{1.16} & 0.040 & 9.9 & 10.8 & 12.6 & 13.9 & 16.6 & 7 \\
\cline { 2 - 7 } & 0.031 & 7.7 & 8.4 & 9.7 & 10.8 & 12.8 & 5 \\
\hline \multirow{2}{*}{0.75} & 0.040 & 8.0 & 9 & 10.7 & 12.1 & 14.7 & 7 \\
\cline { 2 - 7 } & 0.031 & 6.2 & 6.9 & 8.3 & 9.3 & 11.4 & 5 \\
\hline
\end{tabular}

Table 10. The minimal insulation thickness for a flat roof

\begin{tabular}{cccccccc}
\hline \multirow{2}{*}{$\begin{array}{c}\text { Initial value } U \\
{\left[\mathrm{~W} \mathrm{~m}^{-2} \mathrm{~K}^{-1}\right]}\end{array}$} & $\begin{array}{c}\lambda \text { of insulation } \\
\text { material } \\
{\left[\mathrm{W} \mathrm{m} \mathrm{m}^{-1} \mathrm{~K}^{-1}\right]}\end{array}$ & \multicolumn{5}{c}{$d$-insulation thickness [cm] } \\
\cline { 3 - 7 } & 0.30 & 0.25 & 0.20 & 0.18 & 0.15 & $\Delta d$ trade [cm] \\
\cline { 2 - 7 } 1.70 & 0.043 & 11.8 & 14.7 & 19.0 & 21.4 & 26.1 & 15 \\
\cline { 2 - 7 } & 0.035 & 9.6 & 11.9 & 15.4 & 17.4 & 21.3 & 12 \\
\hline \multirow{2}{*}{1.20} & 0.043 & 10.8 & 13.6 & 17.9 & 20.3 & 25.1 & 15 \\
\cline { 2 - 7 } & 0.035 & 8.8 & 11.1 & 14.6 & 16.5 & 20.4 & 12 \\
\hline
\end{tabular}




\section{Conclusion}

Energy-saving policy used in Poland since 1974 and proposed to 2021 is the good example of influence of energy policy on energy conservation.

From the analysis conducted, it appears that in the considered period, substantial decrease of heat transfer coefficients (U) occurred for several times in Poland. When it come to the technical building regulations, in force since January 2014, further limitations of this parameter are imposed.

The boundary value of the demand index for nonrenewable primary energy EP decreased considerably for different types of buildings.

The modifications introduced impose meeting both requirements of $U$ and EP, not only $U$ or only EP as it was so far. The limitation on the value of $U$ coefficients forces the application of bigger thicknesses of thermal insulation for sample partitions i.e. $7 \mathrm{~cm}$ or 5 $\mathrm{cm}$ for an external wall, and $12 \mathrm{~cm}$ or $15 \mathrm{~cm}$ for a flat roof depending on the heat conductivity coefficient of an insulation material. All the described modifications to thermal insulation cause the reduction of heat consumption in a building which leads to the limitation of carbon dioxide emissions into the atmosphere. Consequently, such a phenomenon contributes to the realisation of the Polish Energy Policy premises.

\section{References}

1 Pérez-Lombard L., Ortiz J., Pout C. A review on buildings energy consumption information. Energy and Buildings 40 (2008) 394-398.

2 Poel B., Cruchten G., Balaras C.A. Energy performance assessment of existing dwellings. Energy and Buildings 39 (2007) 393-403.

3 Ueno T., Inada R., Saeki O., Tsuji K. Effectiveness of an energy-consumption information system for residential buildings. Applied Energy 83 (2006) 868-883.

4 Ouyang J., Hokao K. Energy-saving potential by improving occupants' behavior in urban residential sector in Hangzhou City, China. Energy and Buildings 41 (2009) 711-720.

5 De Almeida A.T., Lopes A., Carvalho A., Mariano J., Nunes C. Evaluation of fuel-switching opportunities in the residential sector. Energy and Buildings 36 (2004) 195-203.

6 Cholewa T., Siuta-Olcha A., Skwarczyński M.A. Experimental evaluation of three heating systems commonly used in the residential sector. Energy and Buildings 43 (2011) 2140-2144.

7 Gustafsson S.I., Rönnqvist M. Optimal heating of large block of flats. Energy and Buildings 40 (2008) 1699-1708.

8 Yuan C., Liu S., Fang Z., Wu J. Research on the energy-saving effect of energy policies in China:1982-2006. Energy Policy 37 (2009) 2475-2480.

9 Życzyńska A. The use of audit and the energy certificate for building by management of real estate. Civil Engineering and Architecture 12 (2013) 107-116, (in polish).

10 Życzyńska A. Changes in law about supporting of thermomodernisation undertakings and executive regulations. Market of Energy 6 (2002) 48-51, (in polish).

11 Zhang L. Model projections and policy reviews for energy saving in China's service sector. Energy Policy 59 (2013) 312-320.

12 Zhao X., Li H., Wu L., Qi Y. Implementation of energy-saving policies in China: How local governments assisted industrial enterprises in achieving energy-saving targets. Energy Policy 66 (2014) 170-184.

13 Eurostat Available from: (http://www.ec.europa.eu/eurostat)

14 Polish Standard, 1974. PN-74/B-03404 Heat transfer coefficient for building partitions (in polish).

15 Polish Standard, 1982. PN-82/B-02020 Heat insulation of buildings. Requirements and calculations (in polish). 
16 Polish Standard, 1991. PN-91/B-02020 Heat insulation of buildings. Requirements and calculations (in polish).

17 The Decree of Minister of Infrastructure, 2002. On technical requirements which buildings and their location should comply with. (Journal of Laws No. 75/2002, item 690 with later modifications). Available on 12.04.2002, (in polish).

18 The Decree of Minister of Infrastructure, Construction and Maritime Economy, 2013. Modifying the regulation on technical requirements which buildings and their location should comply with. (Journal of Laws of 13.08.2013, item 926). Available on 5.07.2013, (in polish).

19 The Act of supporting thermomodernisation projects, 1998. (Journal of Laws No. 162/98, item 1121 with later modifications). Available on 18.11.1998, (in polish).

20 The Act of supporting thermomodernisation and renovation, 2008. (Journal of Laws 223/2008, item 1459 with later modifications). Available on 21.11.2008, (in polish).

21 The Decree of Minister of Infrastructure, 2009. On detailed range and forms of energy audit and the part of repair audit, sample audit cards, and the algorithm of profitability evaluation of thermomodernisation project. (Journal of Laws No. 43/2009, item 346). Available on 17.03.2009, (in polish).

22 Polish Standard, 2001. PN-B-02025:2001 Calculating the seasonal heating demand to heat residential and multi-apartment buildings (in polish).

23 The Decree of Minister of Infrastructure, 2008. On the methodology of energy characteristics calculations of a building, housing unit or a building part being independent as a technicalusable whole and the procedures to prepare the samples of their energy characteristics. (Jounal of Laws No. 201/2008, item1240). Available on 6.11.2008, (in polish).

24 EN ISO 13790:2008 Energy performance of buildings - Calculation of energy use for space heating and cooling

25 EN ISO 6946:2007 Building components and building elements. Thermal resistance and thermal transmittance. Calculation method. 